\title{
Role of Muscle Free Flap in the Salvage of Complicated Scalp Wounds and Infected Prosthetic Dura
}

\author{
Dae Hee Han, Myong Chul Park, Dong Ha Park, Hyunsuk Song, Il Jae Lee \\ Department of Plastic and Reconstructive Surgery, Ajou University Hospital, Ajou University School of Medicine, Suwon, Korea
}

Background The prosthetic dura is an essential element in the protection of the cranial parenchyma and prevention of cerebrospinal fluid leakage. Although prosthetic dura are widely used in neurosurgery, they occasionally provoke infection, which can be a major concern after neurosurgical treatment. However, removal of the prosthetic dura carries a risk of brain parenchyma injury and cerebrospinal fluid leakage. The salvage of infected prosthetic dural material has not been adequately addressed in the literature. In this study, we demonstrate the value of the combination of a meticulous surgical debridement of necrotic tissue and simultaneous muscle free flap for intractable postoperative epidural abscess without removal of the infected prosthetic dura.

Methods Between 2010 and 2012, we reviewed the data of 11 patients with persistent infection on the prosthetic dura. The epidural infections each occurred after a neurosurgical procedure, and there was soft tissue necrosis with the disclosure of the underlying prosthetic dura and dead bone around the scalp wound. To salvage the infected prosthetic dura, meticulous debridement and a muscle free flap were performed.

Results All 11 patients experienced complete recovery from the complicated wound problem without the need for further surgical intervention. No signs of prosthetic dural infection were observed during the mean follow-up period of 11 months.

Conclusions The combination of a meticulous surgical debridement and coverage with a muscle free flap is an effective treatment for salvage of infected prosthetic dura.

Keywords Free tissue flaps / Epidural abscess / Salvage therapy / Prosthesis-related infections
Correspondence: II Jae Lee Department of Plastic and Reconstructive Surgery, Ajou University Hospital, Ajou University School of Medicine, 164 World Cupro, Yongtong-gu, Suwon 443-721, Korea

Tel: $+82-31-219-5614$

Fax: +82-31-219-5610

E-mail: i00325@live.co.kr

No potential conflict of interest relevant to this article was reported.

\section{INTRODUCTION}

Dura defects often result from extensive resection of the bone and dura to treat tumors, chronic infections, osteroradionecrosis, trauma, burns, or congenital lesions. If the defect is not properly reconstructed, it will bring about a leakage of cerebrospinal fluid (CSF) and the possibility of secondary contamination [1]. Prosthetic dural materials, such as non-autologous and bovine pericardial grafts, are widely utilized in neurosurgery because they cover the dura defect and provide a watertight seal that prevents CSF leakage $[2,3]$. However, persistent and troublesome wound infections can prelude the development of life threaten-

Copyright () 2013 The Korean Society of Plastic and Reconstructive Surgeons

This is an Open Access article distributed under the terms of the Creative Commons Attribution Non-Commercial License (http://creativecommons.org/

licenses/by-nc/3.0/) which permits unrestricted non-commercial use, distribution, and reproduction in any medium, provided the original work is properly cited.

www.e-aps.org 
ing infective complications. Thus, it is important to solve the dural wound problem as soon as possible to prevent the dissemination of the infection into the intracranial space.

Controversy exists in the management of these grafts in infected wounds, and there is no gold standard for the management of this problem. As a result, some authors suggest that removal of the artificial material may be feasible. However, removing the dural patch and its replacement in infected and inflamed tissue may cause difficulty $[3,4]$. A muscle free flap is reported to be effective in the case of protracted and infected wounds because a good blood supply within the muscle can clear infections and ensure rapid wound recovery $[5,6]$. We experienced that reconstruction of large scalp defects after debridement of the infected tissue with free muscle flaps can be very effective for infected prosthetic dura salvage.

In this article, we demonstrate our experience with 11 cases of postoperative epidural infection managed with surgical debridement and muscular free flap coverage. Advantages and disadvantages are reviewed, and surgical technical tips are discussed.

\section{METHODS}

Between 2010 and 2012, we experienced 11 patients ( 6 men and 5 women) with infected prosthetic dura. All of the patients experienced epidural inflammation after a neurosurgical procedure that required surgical intervention for control. The original craniotomy was performed in 9 patients for trauma, one for subarachnoid hemorrhage, and one for brain tumor. Six patients had been recipients of bovine pericardial grafts (Lyoplant, B. Braun, Tuttlingen, Germany) used for coverage of a dura defect at the time of the original craniotomy. The other five patients received artificial dura (Neuro-Patch, B. Braun). After the craniotomy, infection of the prosthetic dura took 5.4 months on average to appear. From the open wound, there was pus-like discharge with a draining sinus. Wound cultures showed the existence of methicillin-resistant Staphylococcus aureus in five patients, Pseudomonas aeruginosa in two patients, and methicillinresistant coagulase-negative Staphylococcus in five patients (Table 1).

Around the scalp wound, there was soft tissue necrosis with the exposure of the underlying prosthetic dura and infected bone (Fig. 1). An abscess had not yet formed in the subdural area, which was confirmed by brain computed tomography (CT). Therefore, the infected soft tissue needed to be replaced immediately with well-vascularized healthy tissue. In all of the patients, several previous surgical interventions were made to resolve the problem by the attending neurosurgeons, without success. They involved wound irrigations with antibiotics, systemic

Table 1. Eleven patients received muscle free flap for salvage of infected prosthetic dura

\begin{tabular}{|c|c|c|c|c|c|c|c|c|c|c|}
\hline Case & $\begin{array}{c}\text { Sex/Age } \\
\text { (yr) }\end{array}$ & Diagnosis & $\begin{array}{l}\text { Defect size } \\
\left(\mathrm{cm}^{2}\right) / \text { Site }\end{array}$ & $\begin{array}{l}\text { Recipient } \\
\text { artery }\end{array}$ & $\begin{array}{l}\text { Flap size } \\
\left(\mathrm{cm}^{2}\right)\end{array}$ & $\begin{array}{c}\text { Prosthetic } \\
\text { dura }\end{array}$ & $\begin{array}{l}\text { Latency from } \\
\text { original } \\
\text { craniotomy (mo) }\end{array}$ & Bacteria & Treatment & $\begin{array}{l}\text { Follow-up } \\
\text { (mo) }\end{array}$ \\
\hline 1 & $F / 63$ & Subdural empyema & $\begin{array}{c}10 \times 3 / \\
\text { Parietal area }\end{array}$ & $\begin{array}{c}\text { Superficial } \\
\text { temporal artery }\end{array}$ & $12 \times 4$ & Neuro-Patch & 15 & $\begin{array}{c}\text { Pseudomonas } \\
\text { aeruginosa }\end{array}$ & $\begin{array}{l}\text { Gracilis muscle } \\
\text { free flap }\end{array}$ & 18 \\
\hline 2 & $\mathrm{M} / 44$ & Subdural hemorrhage & $\begin{array}{c}8 \times 5 / \\
\text { Parietal area }\end{array}$ & $\begin{array}{c}\text { Superficial } \\
\text { temporal artery }\end{array}$ & $10 \times 8$ & Neuro-Patch & 10 & MRSA & $\begin{array}{l}\text { Rectus abdominis } \\
\text { muscle free flap }\end{array}$ & 15 \\
\hline 3 & $\mathrm{~F} / 40$ & $\begin{array}{l}\text { Subarachnoid } \\
\text { hemorrhage }\end{array}$ & $\begin{array}{c}10 \times 7 / \\
\text { Temporoparietal } \\
\text { area }\end{array}$ & $\begin{array}{c}\text { Superficial } \\
\text { temporal artery }\end{array}$ & $12 \times 9$ & Lyoplant & 3 & MRSA & $\begin{array}{l}\text { Vastus lateralis } \\
\text { muscle free flap }\end{array}$ & 9 \\
\hline 4 & $\mathrm{M} / 20$ & Gunshot injury & $\begin{array}{c}8 \times 4 \text { / } \\
\text { Infratemporal } \\
\text { fossa }\end{array}$ & Lingual artery & $10 \times 6$ & Lyoplant & 5 & $\begin{array}{l}\text { MRSA, } \\
\text { MRCNS }\end{array}$ & $\begin{array}{l}\text { Vastus lateralis } \\
\text { muscle free flap }\end{array}$ & 8 \\
\hline 5 & $\mathrm{~F} / 30$ & Crushing injury & $\begin{array}{c}9 \times 7 / \\
\text { Occipital area }\end{array}$ & Occipital artery & $11 \times 8$ & Neuro-Patch & 2 & MRCNS & $\begin{array}{l}\text { Latissmus dorsi } \\
\text { free flap }\end{array}$ & 9 \\
\hline 6 & $\mathrm{M} / 46$ & Skull fracture & $\begin{array}{c}6 \times 5 / \\
\text { Temporal area }\end{array}$ & $\begin{array}{l}\text { Transverse } \\
\text { cervical artery }\end{array}$ & $7 \times 6$ & Neuro-Patch & 2 & MRCNS & $\begin{array}{l}\text { Vastus lateralis } \\
\text { muscle free flap }\end{array}$ & 12 \\
\hline 7 & $\mathrm{M} / 68$ & Epidural hemorrhage & $\begin{array}{c}10 \times 5 / \\
\text { Parietal area }\end{array}$ & $\begin{array}{c}\text { Superficial } \\
\text { temporal artery }\end{array}$ & $12 \times 6$ & Lyoplant & 3 & $\begin{array}{c}\text { Pseudomonas } \\
\text { aeruginosa }\end{array}$ & $\begin{array}{l}\text { Latissmus dorsi } \\
\text { free flap }\end{array}$ & 13 \\
\hline 8 & $\mathrm{M} / 56$ & Subdural hemorrhage & $\begin{array}{c}9 \times 9 / \\
\text { Temporoparietal } \\
\text { area }\end{array}$ & $\begin{array}{l}\text { Superficial } \\
\text { temporal artery }\end{array}$ & $10 \times 11$ & Lyoplant & 4 & MRCNS & $\begin{array}{l}\text { Vastus lateralis } \\
\text { muscle free flap }\end{array}$ & 11 \\
\hline 9 & $\mathrm{M} / 60$ & Skull fracture & $\begin{array}{c}8 \times 7 / \\
\text { Temporal fossa }\end{array}$ & Facial artery & $9 \times 8$ & Lyoplant & 5 & MRCNS & $\begin{array}{l}\text { Latissmus dorsi } \\
\text { free flap }\end{array}$ & 10 \\
\hline 10 & $\mathrm{~F} / 72$ & Subdural hemorrhage & $\begin{array}{c}3 \times 3 / \\
\text { Parietal area }\end{array}$ & $\begin{array}{c}\text { Superficial } \\
\text { temporal artery }\end{array}$ & $4 \times 4$ & Lyoplant & 5 & MRSA & $\begin{array}{l}\text { Gracilis muscle } \\
\text { free flap }\end{array}$ & 10 \\
\hline 11 & $F / 43$ & Glioblastoma & $\begin{array}{c}9 \times 4 / \\
\text { Temporal area }\end{array}$ & $\begin{array}{c}\text { Transverse } \\
\text { cervical artery }\end{array}$ & $10 \times 5$ & Neuro-Patch & 6 & MRSA & $\begin{array}{l}\text { Vastus lateralis } \\
\text { muscle free flap }\end{array}$ & 12 \\
\hline
\end{tabular}


Fig. 1. Preoperative and intraoperative photographs of case 2

(A) A 44-year-old male patient presented with soft tissue necrosis at the previous neurosurgical operation wound. (B) The wound contained soft tissue loss with the exposure of the underlying prosthetic dura (Neuro-Patch, white arrow) and dead bone.

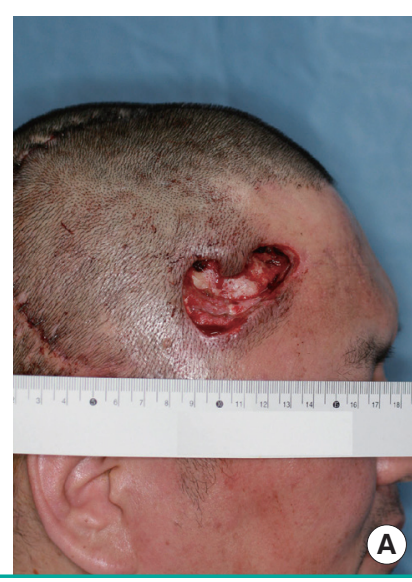

A

\section{Fig. 2. Immediate postoperative photograph of case 3}

A muscular flap was used to fill the defect, and local skin flaps and a split skin graft meshed 1.5:1 from the thigh were used to cover the outer margins of the flap.

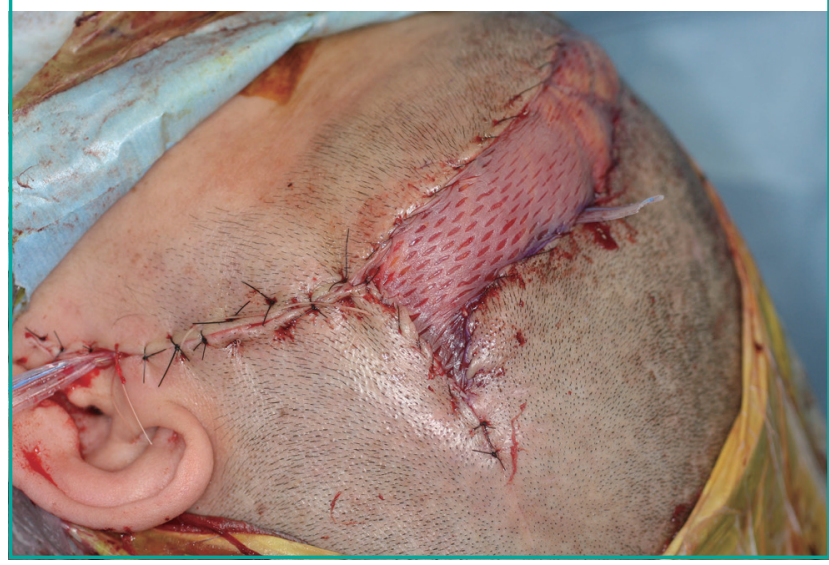

antibiotic administration, debridement, and local flap coverage.

We performed a single step, two-team approach. At first, the neurosurgical operation team made a skin incision and careful debridement and irrigation of the infected bone and the dura mater was performed. After that, the prosthetic dura was exposed.

The second surgical team, the plastic and reconstructive surgical operation team, carried out the debridement of the infected skin and soft tissue and harvested muscle flap. With preservation of the prosthetic dura, meticulous debridement was done until healthy tissue appeared by removing the biofilm, including granulation tissue and the adherent bacteria. The muscle flap was harvested without a skin island according to the size of the defect from two gracilis muscles, one rectus abdominis muscle, three latissmus dorsi, and five vastus lateralis muscles.

Utilization of the superficial temporal vessels is frequently limited by multiple previous craniotomies or preoperative radiation. Thus, we dissected the pedicle as far as possible to permit

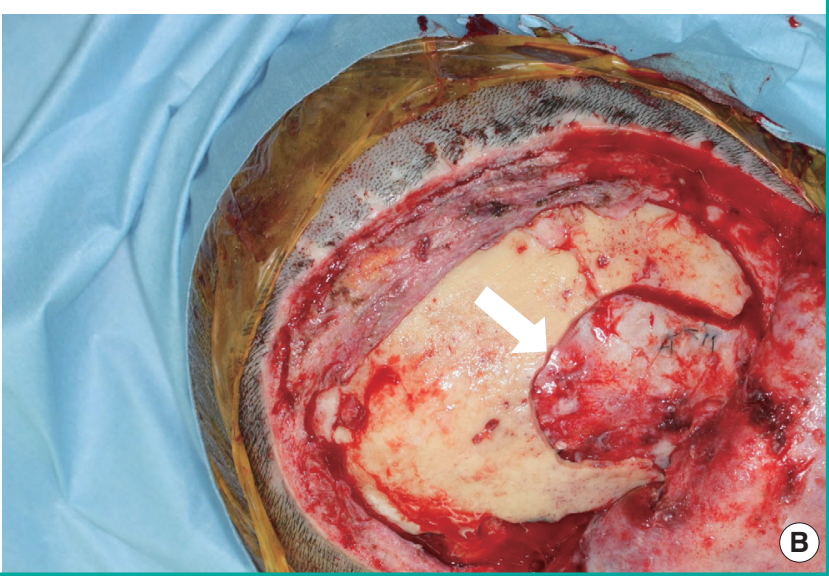

more efficient microvascular anastomosis without a vein graft. The length of the pedicle ranged from 8 to $14 \mathrm{~cm}$. For microvascular anastomosis, the recipient arteries used were the superficial temporal artery in six patients, transverse cervical artery in two patients, occipital artery in one patient, facial artery in one patient, and lingual artery in one patient. The soft tissue defect was completely filled with a muscle flap protecting the vessels and prosthetic dura. We allowed any extra amount of bulging to protrude. The local skin flaps and split skin graft meshed 1.5:1 from the thigh were used to cover the outer margins of the flap (Fig. 2). To prevent hematoma, a negative-pressure drain was placed below the flap and mild compressive dressing was applied over the flap site.

In all cases, blood samples were acquired preoperatively and postoperatively to follow-up the level of inflammation by checking the white blood cell count, erythrocyte sedimentation rate, and C-reactive protein level. A brain CT scan was done for each patient to check the change of the intracranium. We used broadspectrum intravenous antibiotics first, and after the identification of an organism, adjusted the antibiotic regimen appropriately.

\section{RESULTS}

All free tissue transfers were performed successfully. There were no flap-related complications such as necrosis, ischemia, or partial loss of a flap among the patients, yielding an overall flap success rate of $100 \%$. The patients were nursed for 48 hours in intensive care and recovery was complete. According to the results of follow-up blood samples and brain CT, no signs of postoperative complications such as infection, hematoma, CSF leakage, or calvarial osteomyelitis were seen (Fig. 3). No major donor-site morbidities, such as hematoma, seroma, wound dehiscence, functional or aesthetic impairments, or herniation 


\section{Fig. 3. Computed tomography from case 1}

(A) Preoperative contrastenhanced computed tomography revealed an abscess on the left temporal area. Fluid collection was evident above the prosthetic dura (white arrow). (B) Prosthetic dura successfully salvaged with the muscle flap was seen at 3 months postoperatively. There was no sign of inflammation around the prosthetic dura.
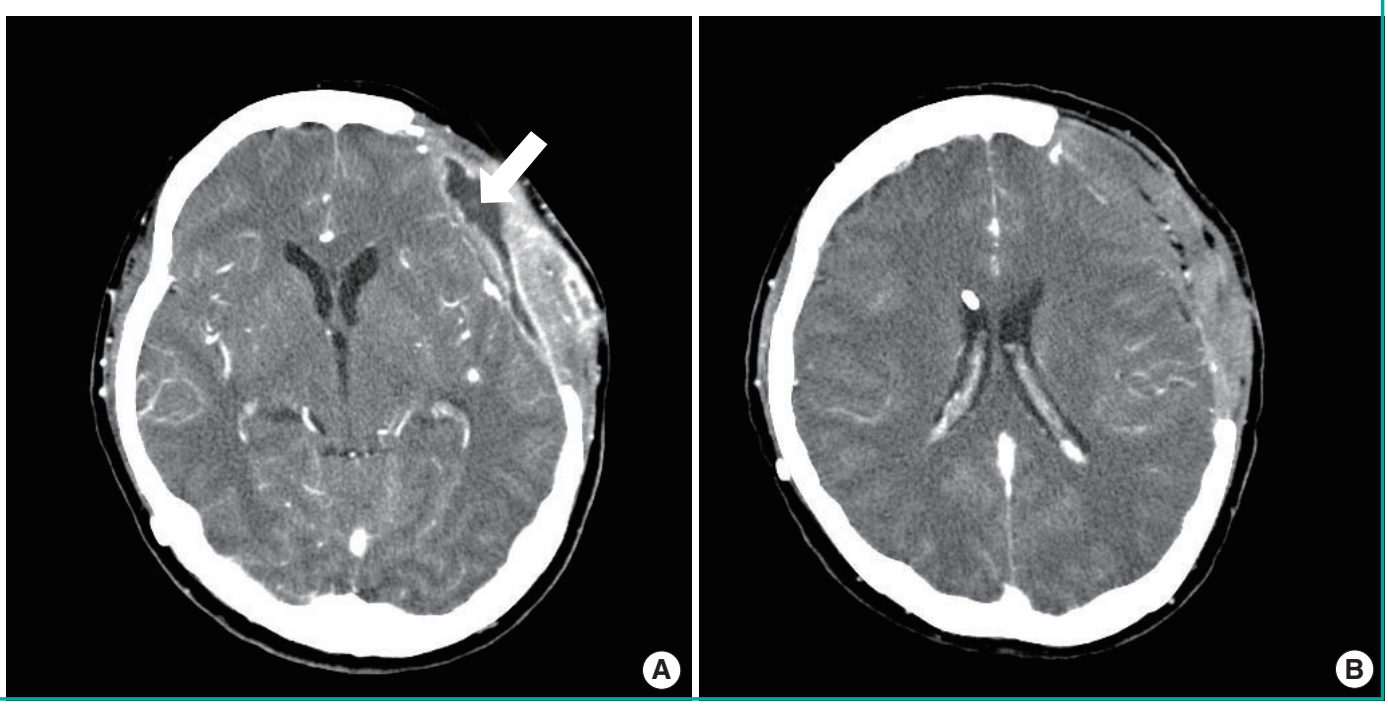

Fig. 4. Follow-up appearance for case 2

(A) The flap protruded over the scalp contour after 2 weeks of followup. (B) Muscular atrophy and skin retraction occurred within 3 months, improving the cranial contour.
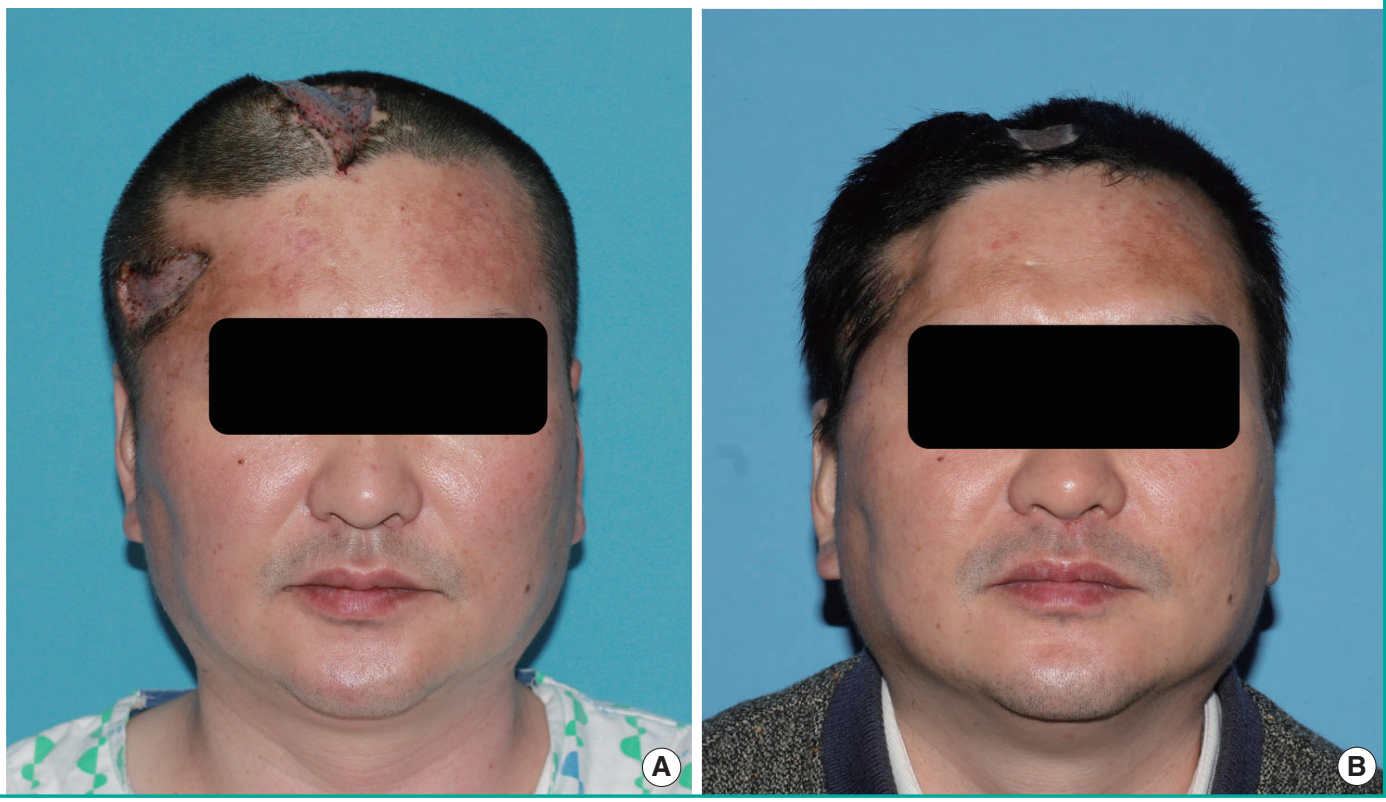

were observed. All of the patients were successfully treated without relapse of infection with a mean follow-up of 11 months (Table 1). The muscular atrophy allowed satisfactory or good results for the cranial contour (Fig. 4).

\section{DISCUSSION}

The leakage of CSF is a relatively common complication after neurosurgery, such as cranial or spinal surgery. Persistent leaks endanger patients from serious intracranial complications [7]. Bovine pericardial tissue and synthetic, non-absorbable dura substitutes provide a watertight seal, thus preventing CSF leaks. Thus, among neurosurgeons, they have become essential tools for coverage of dura defects. These prosthetic dura are inexpensive, pliable, non-toxic, fluid-impermeable, unlikely to adhere to the meninges, easily sterilized, and conducive to suture placement $[2,8]$. However, prosthetic dura is a foreign material, and therefore is vulnerable to infection. Once infection arises, antibiotics lose their control, bring about progression of chronic inflammation due to restricted blood circulation. Our patients experienced persisting infection of the prosthetic dura after neurosurgical procedures, despite multiple debridement and systemic antibiotic therapy. They all needed proper reconstruction by appropriate debridement and a flap with good circulation coverage $[9,10]$.

Generally, the removal of foreign material from an infected 
wound is recommended to achieve wound healing. After that, some authors have achieved good results from the removal of infected prosthetic dura and reconstruction of the dura defect and dead space with a vascularized musculocutaneous free flap $[1,3]$. This may be a good option in some situations. However, the re-exploration rates of free flap in the literature range from $6 \%$ to $14 \%$, with subsequent small numbers of complete flap losses [11]. Therefore, this treatment modality does not take into account the risk of procedures in which removal of the prosthetic dura may cause the loss of control of the CSF sealing and increase the risk of intracranial infection. Moreover, that may put the cranial parenchyma at risk [12]. If these methods are not successful, the brain parenchyma would be directly exposed to infected tissue.

We tried to salvage the infected prosthetic dura for the following reasons. First, as CSF is circulating under the dura, complete sealing is required to prevent leakage of the fluid [13]. If the infected prosthetic dura is removed, sealing can be performed by close suturing using the fascial layer with a muscle free flap as the substitute $[1,12]$. However, a watertight suture between the dura and fascial layer may increase the pressure around the supplying vessels of the free flap where the pedicle penetrates the fascia. As a result, circulatory failure of the flap may occur [12]. It is difficult to create complete watertight coverage without a prosthetic dura.

Second, after depressed craniotomy, the flap in the depressed state may affect the cranial parenchyma, leading to development of the sinking skin flap syndrome $[14,15]$. Surgery causes adhesion in the field, leading to cranial parenchyma-dura mater-muscle flap deformation. As a result, the local circulation may be disrupted, precipitating a brain function disorder. This sinking skin flap syndrome may develop when the fascia and flap directly come into contact with the cranial parenchyma. Postoperatively, strict follow-up and early cranioplasty are warranted [12].

Lastly, reconstruction of the dura defect and dead space with a musculocutaneous flap creates a large donor site defect. The main trouble in harvesting a portion of the fascia with the muscle is closure of the fascia defect. Donor site morbidity, bulging or hernia, and weakening of the muscle are potential risks [1].

The risk of removal and replacement exceeds that of salvage. This argument is also supported by the observation that prosthetic material in an infected wound may be salvaged without immediate removal [3]. Presently, we adopted a strategy for salvaging the infected prosthetic dura with a muscle free flap. In general, the main reason for failure of salvage procedures is incomplete infection eradication. If the wound is debrided incompletely, the periprosthetic environment develops into a rich bacterial culture medium. Moreover, antibiotics lose their control over bacteria sequestered in biofilms [16]. A lasting infection may be evidence that extensive and radical wound debridement had not been performed properly. The main aim of our strategy was the eradication of all necrotic tissues and high bacteria-count granulation tissue. After that, to preserve the prosthetic dura, the soft tissue defect was covered with a highdensity vascular complex (i.e., a muscular flap). This strategy causes inflammatory cytokines from the vascular circulation to come in contact with the bacteria, promoting phagocytosis [9].

Several factors should be considered before scalp reconstruction, such as the anatomic involvement of defects, depth of injury with simultaneous understanding of existing problems, and the general condition of patient status [17]. Coverage of a scalp defect with local flaps is mainly performed as a single- or multiple-stage procedure [18]. However, it can be difficult to fulfill both the structural and protective need for scalp coverage when the defects extend to $200 \mathrm{~cm}^{2}$ on the scalp [19]. Although the size of the defect was small in our cases, the surrounding tissue was infectious and contained scar tissue from a previous operation, and the circulation was compromised. In such cases, local flaps are not suitable and free flaps should be considered [19]. An ideal tissue would be one that can endure radiation and trauma and heal easily, which enables the timely administration of adjuvant therapies [20], notwithstanding a hairless reconstruction.

Advances in microsurgery have allowed more reliable wound closures with less morbidity, while achieving a single-stage operation, even in the setting of infection or radiation. Traumatized tissue or irradiated tissue with poor circulation around defects leads to a high risk of local flap failure [5,21].

The fasciocutaneous free flap has a cutaneous paddle that has proven to be more robust than a skin graft, and the thickness of the flap is cosmetically appealing [17]. However, chronic wounds with unhealthy adjacent tissues develop, fasciocutaneous flaps alone cannot provide the proper volume to obliterate the "dead space" between the calvaria and the surrounding unhealthy scalp $[21,22]$. In the case of coexistent chronic infections, such as osteomyelitis, a well vascularized muscle-only flap can overcome this problem $[5,21]$. The use of a muscle flap with a split-thickness skin graft for scalp reconstruction can afford maximal flexibility of tissue for a large defect and becomes an appropriate thickness after atrophy, closely resembling the natural scalp [23]. Moreover, it can tightly confine the surrounding margin to encourage better wound healing and prevent CSF leakage $[21,24]$.

We had chosen a muscular flap, according to the dimensions of the defect, covered with split skin grafts. This allowed protection of the brain, single-stage wound coverage, and bulkiness 
that finally brought about a close-to-normal appearance of the cranium. Grafted skin retraction occurred simultaneously with muscle atrophy during the first 3 postoperative months, further improving the cranial contour, which revealed no major irregularity.

Presently, two gracilis flaps, one rectus abdominis flap, three latissmus dorsi, and five vastus lateralis flaps were applied. The gracilis muscle flap was used for a small defect and the rectus abdominis muscle unit for a medium-sized defect. The rectus abdominis muscle flap has been a useful flap for deficits in the head and neck. This flap is preferable because of its reliable vascular supply, ease of harvesting without the need to reposition the patient, and minimal donor-site morbidity [25]. The vastus lateralis flap has the advantages of involving sufficient length of the pedicle with a proper diameter for anastomoses and acceptable donor site morbidity.

In our study, there was no postoperative donor or recipient site morbidity, such as infections, CSF leaks, or signs of meningitis. The salvaged prosthetic dura maintained a watertight closure of the dura mater. In the case of chronic unhealed wounds, we demonstrated that vascularized muscle flaps can be useful in decreasing infectious complications. Moreover, if the patient desires improved structural integrity, a second-stage procedure can be done to reconstruct the cranium using autologous bone grafts. Although the shortcomings of the study are a small patient population and short follow-up period, our treatment strategy demonstrated successful salvage of the infected prosthetic dura. This strategy can be accomplished safely and effectively by a microvascular surgeon with excellent results. We argue that meticulous debridement followed directly by free muscle flap coverage can be a highly efficacious reconstructive option.

\section{REFERENCES}

1. West CA, Towns G, Bachelor AG, et al. Reconstruction of skull base and dura using rectus abdominis muscle combined with a vascularised fascial perforator flap. J Plast Reconstr Aesthet Surg 2006;59:631-5.

2. Anson JA, Marchand EP. Bovine pericardium for dural grafts: clinical results in 35 patients. Neurosurgery 1996;39: 764-8.

3. Chung C, Forte AJ, Momeni R, et al. Muscle-flap salvage of prosthetic dural repair. J Plast Reconstr Aesthet Surg 2010; 63:213-7.

4. Weber SM, Kim J, Delashaw JB, et al. Radial forearm free tissue transfer in the management of persistent cerebrospinal fluid leaks. Laryngoscope 2005;115:968-72.

5. Lutz BS, Wei FC, Chen HC, et al. Reconstruction of scalp defects with free flaps in 30 cases. Br J Plast Surg 1998;51: 186-90.

6. Sanger J, Maiman D, Matloub H, et al. Management of chronic osteomyelitis of the skull using vascularized omental transfer. Surg Neurol 1982;18:267-70.

7. Brodie HA. Prophylactic antibiotics for posttraumatic cerebrospinal fluid fistulae: a meta-analysis. Arch Otolaryngol Head Neck Surg 1997;123:749-52.

8. Narotam PK, Jose S, Nathoo N, et al. Collagen matrix (DuraGen) in dural repair: analysis of a new modified technique. Spine (Phila Pa 1976) 2004;29:2861-7.

9. Boeckx WD, van der Hulst RR, Nanhekhan LV, et al. The role of free flaps in the treatment of persistent scalp osteomyelitis. Neurosurgery 2006;59:ONS64-7.

10. Koshima I, Fukuda H, Yamamoto H, et al. Free anterolateral thigh flaps for reconstruction of head and neck defects. Plast Reconstr Surg 1993;92:421-8.

11. Zhou G, Qiao Q, Chen GY, et al. Clinical experience and surgical anatomy of 32 free anterolateral thigh flap transplantations. Br J Plast Surg 1991;44:91-6.

12. Shimada K, Ishikura N, Heshiki T, et al. Treatment for chronic abscess after cranioplasty: reconstruction of dura maters using the anterolateral thigh flap with fascia lata. J Craniofac Surg 2007; 18:1305-8.

13. Clemenza JW, Kaltman SI, Diamond DL. Craniofacial trauma and cerebrospinal fluid leakage: a retrospective clinical study. J Oral Maxillofac Surg 1995;53:1004-7.

14. Stula D. The problem of the "sinking skin-flap syndrome" in cranioplasty. J Maxillofac Surg 1982;10:142-5.

15. Isago T, Nozaki M, Kikuchi Y, et al. Sinking skin flap syndrome: a case of improved cerebral blood flow after cranioplasty. Ann Plast Surg 2004;53:288-92.

16. Widmer AF. New developments in diagnosis and treatment of infection in orthopedic implants. Clin Infect Dis 2001;33 Suppl 2:S94-106.

17. Ozkan O, Coskunfirat OK, Ozgentas HE, et al. Rationale for reconstruction of large scalp defects using the anterolateral thigh flap: structural and aesthetic outcomes. J Reconstr Microsurg 2005;21:539-45.

18. Lesavoy MA, Dubrow TJ, Schwartz RJ, et al. Management of large scalp defects with local pedicle flaps. Plast Reconstr Surg 1993;91:783-90.

19. Beasley NJ, Gilbert RW, Gullane PJ, et al. Scalp and forehead reconstruction using free revascularized tissue transfer. Arch Facial Plast Surg 2004;6:16-20.

20. Hussussian CJ, Reece GP. Microsurgical scalp reconstruction in the patient with cancer. Plast Reconstr Surg 2002; 109:1828-34. 
21. Chang KP, Lai $\mathrm{CH}$, Chang $\mathrm{CH}$, et al. Free flap options for reconstruction of complicated scalp and calvarial defects: report of a series of cases and literature review. Microsurgery 2010;30:13-8.

22. Lee SS, Huang SH, Chen MC, et al. Management of recurrent ischial pressure sore with gracilis muscle flap and $\mathrm{V}-\mathrm{Y}$ profunda femoris artery perforator-based flap. J Plast Reconstr Aesthet Surg 2009;62:1339-46.

23. Lipa JE, Butler CE. Enhancing the outcome of free latissi- mus dorsi muscle flap reconstruction of scalp defects. Head Neck 2004;26:46-53.

24. Amin A, Rifaat M, Civantos F, et al. Free anterolateral thigh flap for reconstruction of major craniofacial defects. J Reconstr Microsurg 2006;22:97-104.

25. Borah GL, Hidalgo DA, Wey PD. Reconstruction of extensive scalp defects with rectus free flaps. Ann Plast Surg 1995;34:281-5. 